\title{
Social inequalities for student leaders and professional organizations: Florence Nightingale's political legacy
}

\author{
Desigualdades sociais para lideranças estudantis e de organizações profissionais: legado político de Florence Nightingale \\ Desigualdades sociales para liderazgos estudiantiles y de organizaciones profesionales: legado político de Florence Nightingale
}

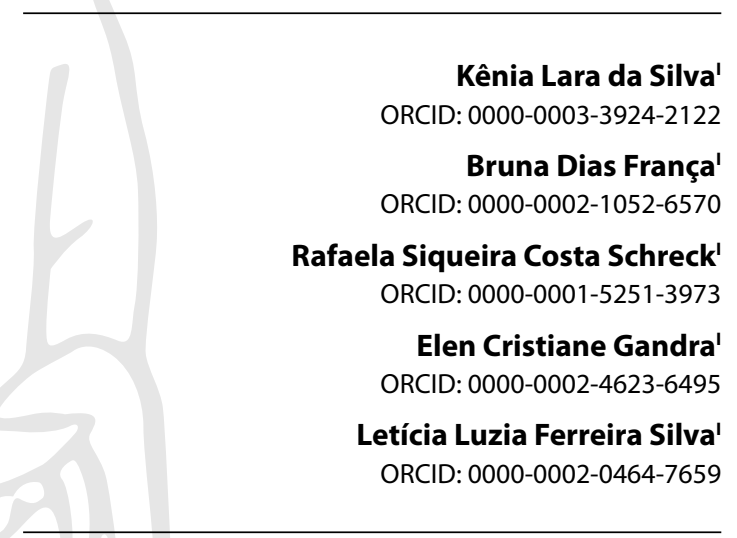

'Universidade Federal de Minas Gerais. Belo Horizonte, Minas Gerais, Brazil.

How to cite this article: Silva KL, França BD, Schreck RSC, Gandra EC, Silva LLF. Social inequalities for student leaders and professional organizations: Florence Nightingale's political legacy. Rev Bras Enferm. 2022;75(2):e20200465. https://doi.org/10.1590/0034-7167-2020-0465

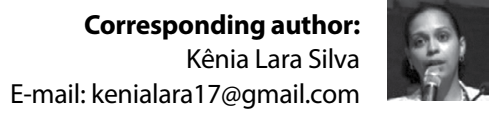

EDITOR IN CHIEF: Dulce Barbosa ASSOCIATE EDITOR: Maria Saraiva

Submission: 07-12-2020

Approval: 04-18-2021

\begin{abstract}
Objectives: to analyze the nursing systems of understanding and social inequalities from the perspective of student leaders and representatives of nursing professional organizations. Methods: qualitative research supported by the theoretical framework of Marxist dialectics. Three representatives of professional organizations and five student leaders participated in the study. Data were obtained from individual interviews and submitted to Critical Discourse Analysis. Results: the discourses are marked by commitment, relational identification and characterize the position of obligation and necessity of nursing in acting with the individuals in situations of inequality, indicating accountability as a social practice. Among the competencies necessary for nursing in confronting social inequalities, political competence is central and is associated with health advocacy. Final Considerations: we conclude that acting on social inequalities is part of the historical construction of nursing. Here, we emphasized the historical importance of Florence Nightingale and her legacy for political action and leadership in nursing.
\end{abstract}

Descriptors: Socioeconomic Factors; Health Advocacy; Leadership; Nursing; Understanding.

\section{RESUMO}

Objetivos: analisar os sistemas de compreensão das desigualdades sociais pela enfermagem, na perspectiva de lideranças estudantis e representantes de organizações profissionais da enfermagem. Métodos: pesquisa qualitativa sustentada no referencial teórico da dialética marxista. Participaram do estudo três representantes de organizações profissionais e cinco líderes estudantis. Os dados foram obtidos de entrevistas individuais e submetidos à Análise de Discurso Crítica. Resultados: os discursos são marcados pelo comprometimento, identificação relacional e caracterizam a posição de obrigação e necessidade da enfermagem em atuar com os indivíduos em situações de desigualdades, indicando a responsabilização como prática social. Dentre as competências necessárias à enfermagem no enfrentamento das desigualdades sociais, a competência política é central e se associa à advocacia em saúde. Considerações Finais: conclui-se que a atuação sobre as desigualdades sociais é parte da construção histórica da enfermagem. Ressalta-se a importância histórica de Florence Nightingale e seu legado para atuação política e liderança da enfermagem.

Descritores: Fatores Socioeconômicos; Advocacia em Saúde; Liderança; Enfermagem; Compreensão.

\section{RESUMEN}

Objetivos: analizar sistemas de comprensión de desigualdades sociales por la enfermería, por perspectiva de liderazgos estudiantiles y representantes de organizaciones profesionales de enfermería. Métodos: investigación cualitativa sustentada en la dialéctica marxista. Participaron del estudio tres representantes de organizaciones profesionales y cinco líderes estudiantiles. Datos fueron obtenidos de entrevistas individuales y sometidos al Análisis de Discurso Crítico. Resultados: discursos son marcados por el comprometimiento, identificación relacional y caracterizan la posición de obligación y necesidad de la enfermería en actuar con los individuos en situaciones de desigualdades, indicando la responsabilización como práctica social. Entre las competencias necesarias la enfermería en el enfrentamiento de desigualdades sociales, competencia política y central y se relaciona la abogacía en salud. Consideraciones Finales: concluye que la actuación sobre las desigualdades sociales y parte de la construcción histórica de la enfermería. Resalta la importancia histórica de Florence Nightingale y su legado para actuación política y liderazgo de enfermería.

Descriptores: Factores Socioeconómicos; Defensa de La Salud; Liderazgo; Enfermería; Comprensión. 


\section{INTRODUCTION}

Nursing has a socio-historical role in facing social inequalities, recognized as the fruit of economic relations that impact social, political, and cultural relations.

Nursing intervention is attributed to a social mandate to promote health equity through collective action, advocacy, and empowerment of vulnerable communities, ensuring access to care and changing the underlying social conditions that perpetuate inequalities ${ }^{(1-2)}$.

Since the beginning of Modern Nursing, whose precursor was Florence Nightingale, with the paradigm of scientific care, nursing professionals are considered protectors of life, including equality in defense of human rights ${ }^{(3)}$. This understanding extends from Florence's first actions, in a war context, an adverse scenario for health, caring for the week and sick in Great Britain, and women and prostitutes in India ${ }^{(4)}$. This action, also marked by religious precepts, gave Florence Nightingale a significant prominence in the history of nursing, not only for her contribution in the scientific organization in the professional field but also in the care of vulnerable groups.

Besides the religious concepts of devotion, charity, love of neighbor, and donation, which influenced Florence in the professional development of nursing, the authors also mention her political activism for changing laws and conditions that created social problems ${ }^{(4)}$.

Based on this comprehension, it is assumed that fighting against inequalities and promoting social justice are in the historical and philosophical roots of the profession ${ }^{(2)}$ since the legacy of Florence Nightingale. However, it becomes necessary to understand how Contemporary Nursing has acted in this movement, incorporating the understanding of inequalities and exercising leadership in this field.

Professional leaderships play a decisive role in confronting social inequalities ${ }^{(5)}$. In this sense, it is believed that outstanding leadership can mark the scenario of a profession, being necessary, for that, actors with enough boldness to take responsibility and believe in the possibilities of their ideas.

However, there are flaws in professional nursing training regarding the development of leadership and the confrontation of social inequalities due to the majority priority of learning technical skills ${ }^{(6-7)}$. Overcoming these limits is the focus of the Nursing Now movement, an initiative campaign of the Organização Mundial da Saúde (World Health Organization) (WHO) and the Conselho Internacional de Enfermeiros (International Council of Nurses), to strengthen nursing, which has leadership as one of its pillars.

The political organization of nursing stands out through its professional associations as spaces to claim the interests of the category and social demands, ensuring the dissemination of studies on issues related to the professional's practices ${ }^{(8)}$.

Thus, it becomes essential to know the perspective of Brazilian nursing leaders to show how the activity in these spaces has the potential for political education and the understanding of social inequalities.

\section{OBJECTIVES}

To analyze systems of understanding of social inequalities by nursing from the perspective of student leaders and representatives of nursing professional organizations.

\section{METHODS}

\section{Ethical aspects}

The research followed the guidelines of Resolution 466/2012 of the Conselho Nacional de Saúde (National Health Council) ${ }^{(9)}$ and began after approval by the Comitê de Ética em Pesquisa (Research Ethics Committee). All interviews were preceded by the signing of the Informed Consent Form (ICF). In the presentation of results, participants are coded with the acronym SL (student leaders) and PO (representatives of professional organizations), both followed by a number indicating the order of the interviews, ensuring confidentiality and anonymity throughout the research process.

\section{Theoretical-methodological framework}

The study is anchored on the theoretical framework of Marxist dialectics, which reveals the process of movement that permanently exists in society and its historical construction and capacity to transform and overcome contradictions through praxis ${ }^{(10)}$.

\section{Type of study}

This research is a descriptive-exploratory study with a qualitative approach. We used the criteria proposed by the Consolidated criteria for reporting qualitative research (COREQ) employed as a roadmap for qualitative research.

\section{Study scenario}

The study was developed in Brazil, with interviews that occurred virtually and in person, according to the availability of participants and researchers. The interviewees were representatives of the Associação Brasileira de Enfermagem (Brazilian Association of Nursing) (ABEn), Associação Brasileira de Obstetrizes enfermeiros Obstetras (Brazilian Association of Obstetricians and Obstetric Nurses) (ABENFO), Associação Brasileira de Enfermeiros de Família e Comunidade (Brazilian Association of Family and Community Nurses) (ABEFACO) and Comitê Estudantil da Associação Brasileira de Enfermagem (Student Committee of the Brazilian Association of Nursing) (COEST).

Among the professional organizations included in the study, the ABEn is the only one with a formal instance in its structure of student participation, represented by COEST. This committee has, among other objectives, the purpose of stimulating the political formation of leaderships for the development of nursing ${ }^{(11)}$, which is why its inclusion in this study is justified.

\section{Methodological procedures}

The data were obtained from interviews with three professionals from nursing professional organizations, at the national level, with recognition for their performance in representing the category. Student members of COEST were also included. The choice of participants was made by purposive sampling.

The first contact with participants was by e-mail, consisting of a brief explanation of the research and an invitation to participate. Four representatives of the professional organizations were 
invited, and three accepted the invitation. These representatives acted in leadership positions within the organizations as members of the national direction of the entities with participation in the management at the time of data collection; and also had experience in previous management of the same association. They were between 40 and 60 years old, two women and one man.

Regarding the students, e-mails were sent to all the leaderships linked to COEST. Five responded to the invitation. The student leaders were linked to public (2) and private (3) universities, from states in the North (1), Northeast (1), Midwest (1), and Southeast (2) regions; they were from the $7^{\text {th }}$ to the $10^{\text {th }}$ period of the undergraduate Nursing school.

\section{Data source}

The data were obtained from individual interviews conducted via Skype and, in two cases, in person. The face-to-face interview provided an opportunity for the researchers to meet with representatives of the associations, and the virtual interview allowed the inclusion of participants from different regions of the country.

\section{Collection and organization of data}

Data collection occurred between December 10, 2018, and August 24, 2019, and was conducted by the researchers who have a nursing background and experience in the procedures used, both in terms of the collection technique and the study referential.

The interview script contained three guiding questions about understanding social inequalities and their relationship to health, the role of nursing in addressing them, and the approach to these issues in training, including the necessary competencies. We tried to allow the free expression of the participants. The interviews were audio-recorded and registered an average duration of 25 minutes and 11 seconds among the students; and 52 minutes and 34 seconds among the representatives of professional organizations.

\section{Data analysis}

The content was transcribed and submitted to Critical Discourse Analysis (CDA). Fairclough ${ }^{(12)}$ refers to the term "discourse" considering it as "language as social practice," which implies taking it as a mode of action upon the world and on others, as well as a mode of representation, in a dialectical relation with the social structure. Therefore, we followed the Social Theory of Discourse proposed by Fairclough ${ }^{(12)}$, which brings the three-dimensional conception of discourse based on text, discourse practice, and social practice.

In the process of analysis, each interview was read in its entirety, individually and independently, by two researchers. Then, it was highlighted, in the texts of the interview, the discursive aspects, especially the modes of operation of ideology (narrativization, universalization, and rationalization), the modalities or mode system (a grammatical resource that indicates the interactive movements of the discourse in the form of the epistemic or deontic modality), and the representation of processes (temporal relations and social actors). The group of researchers validated the markings to verify the level of agreement and avoid individual interpretation bias.

The discursive elements were analyzed and organized for discussion in the following categories: "Understanding social inequalities"; "Skills required to act on social inequalities"; and "Training and learning spaces to deal with social inequalities."

\section{RESULTS}

\section{Comprehension of social inequalities}

The interviewees reveal an understanding of social inequality associated with the differentiation of the economic dimension and social rights related to access to education, health, welfare, and culture. The speeches describe this understanding with the use of the lexical items "economic imbalance," "financial sector," "deprive," and "lack access to opportunities" associated with the concept of inequalities.

I see inequality as a question of imbalance. There is an imbalance in the social issue, an imbalance in the economic issue; it goes through several things. (SL2)

I understand inequalities to be a factor related to the financial sector. Still, so, when we talk specifically social, my understanding is related to social class. (SL4)

I understand that social inequality is depriving, not giving all the fundamental constitutional rights, OK? Like health and public education. (PO2)

Inequality is when people from different social groups do not have access to the same opportunities because of their place. [...] access to goods, services, and living conditions, and even to happiness [...] well-being. (PO3)

It is understood that the participants' discourse reflects the dominant ideology of the analysis of inequalities in the field of economic relations and class differences. Thus, they express a political and moral concept of inequality. They also associate social inequality with access to health, having as determinants housing and living conditions in the outskirts.

Some people benefit more, and in the end, they are not equal, so it's an inequality. (SL5)

I think that difference is something that exists, but when this difference brings harm to some people, it is a matter of dialectics, improvements, or benefits to others; that is when you have inequality in this imbalance. (PO1)

I think that one thing interconnects to the other, [...] the level of available diseases, the level of access to health, or not being able to have access. I think that the difficulty of access and how the peripheries are placed [...] many peripheries don't have primary housing conditions, so health is much less important. (SL3)

In the excerpts cited, it is also possible to identify the discursive strategy of "universalization" to characterize the health conditions in the outskirts and distinguish the assistance provided by professionals in the private sector and public health network.

The participants recognize and highlight, in the interviews, population groups that are directly affected by inequalities: the population of the outskirts, the poor, Indians, the homeless population, black women. Discursively, the strategy of narrativization 
reveals the recognition of the sociohistorical phenomena that point out the origin of the inequalities of these social groups.

Inequality affects women very strongly; the most vulnerable: women, poor people, black people, Indians, is [...] finally [...] the excluded from life, well [...] homeless population, well. [...] and black women, yeah... are, unfortunately, at the top of this inequality, so they are in worse conditions than black men; with black women, they are the end, right? Are the hardest hit by inequality. (PO3)

Many outskirts do not have basic conditions of housing, much less health. (SL3)

The residents have to go through the path to get to the unit [...] these are houses built on a river, so the stability of the structures is not that great. [...] So all of this is unequal. Not to mention the situations of misery and poverty. But [...] it is a lot of things, a lot of stuff [laughs]. Still, we try mostly to attend to the riverside population, whose situation is dire. (SL1)

The understanding of social inequality is presented by a critique to the state's role, described as a structural problem.

The very inequities that promote inequalities are promoted by the state itself, which should promote this access, you know, to this equality. To diminish these inequalities. But on the contrary, it legitimizes it through direct and indirect policies. The Brazilian public health system, despite universal [in nature], is very controversial. It has a political problem. Since the military dictatorship, there has been a law that reduces health care spending, so in a way, it is a direct incentive for people to pay for a health plan. (PO2)

So, first, this [...] social inequality, which is very structural in the society, right? [...] Women, because of their gender specificity, and [...] because they are culturally and socially responsible for the care of the family, for the children, for the older people, they have less opportunity for social advancement and, because of their gender, they still receive lesser payment, which generates an inequality. (PO3)

Discursively, the use of narrativization and rationalization reveals the effects of structural inequality over women, bringing in historical elements and construction of arguments that legitimize this position.

\section{Competencies required to act in face of social inequalities}

The participants'speeches present elements about the necessary competencies for nursing in confronting social inequalities, developing two lines of description of the interventions expected from nurses: one that is associated with more individualized care, with demands on a case-by-case basis; and another that triggers a more collective political role, of participation and social control.

[...] I can't unite my scientific knowledge and try to mitigate these inequalities if I can't have a personalized look at each patient or if my demand doesn't help. (SL1)

I think that nursing has an opening in health education to approach various topics, not only about body care in the field of health but topics about politics, debate, and making the population more involved. (SL3)
The professional [...] has to be encouraged to participate in representative instances such as local councils, seats in the health councils at the municipal, state, and federal levels, in the local health councils. (PO2)

This way, what nursing could be using to fight inequalities would be a voluntary action initiative. I, for example, participate in several actions. (SL5)

The discourses are marked by commitment, relational identification, and epistemic and deontic modalities, which characterize the profession's position of obligation and necessity in "to have,"'to have how," and "being able to be" acting with individuals in situations of inequality.

There is mention of a nursing political role presented by expressions that modulate the statements (I see it like this, do you understand? I think it is so, like this) in a discourse created by associating evaluative expressions, such as "expanded" and "those that go beyond," intertextually referring to the notion of field and core of professional knowledge.

Gastão Wagner [CAMPOS] talks a lot about the field competencies necessary for the health worker in their field of specialty; they are more expanded competencies. So, field competencies, developed competencies, or those who extrapolate the field of specific competencies put us in a place of engagement, expanding the participation, and calling collectives for organized action! (PO3)

Nursing against these inequalities, I see it this way; [...] of getting involved in issues of struggles of the populations that live this inequality daily, [...]. Of being involved in the matters even within the city where the campus is located, involvement with the issues of class struggles, you know? Because all this goes through to meet these inequalities. (SL2)

I think there are exciting actions, like [...] when nursing is engaged, from the point of view of political engagement, activism. Anyway [...] as social agents, we work to reduce poverty for the inclusion of more vulnerable populations. (PO3)

Just the advocacy and political competence, the participants listed communication and leadership and other attributes and skills necessary for nurses to achieve success in confronting social inequalities: creativity, humanization, insight, ethics.

Idon't know if we can call them competencies, but've heard this name mentioned a lot in promotion; the promotion teachers mention it a lot, that it's that advocacy thing, you know, advocating for someone and speaking out for someone. Let me see what else there is; I don't know if this would be exactly a competence, but there is an issue of humanization. (SL4)

So, if I could list competencies, it would be three: leadership, communication, and discernment, that I can remember because I think this is very important because we lack a lot of that. (SL1)

Political competence, communication, and leadership. (SL2)

Opinion and ethics because they are the principle. If we have ethics, we won't have inequality. (SL5) 


\section{Spaces of formation and learning to deal with social inequalities}

The participants established a criticism of the professional nursing training regarding how undergraduate courses address the theme of social inequalities. They mention that social inequalities are approached occasionally, prompted by students' questions and doubts, or by isolated initiatives of specific disciplines and in non-mandatory course activities.

Isee a demand for more peers; in this case, nursing students. (SL2)

[Are these competencies acquired or developed during the academics training at your institution?] Unfortunately, not. I guess we receive a lot of it when we start in the militia [...]. I don't think the academy would provide anything for us. (SL3)

In my course, inequalities are restricted. The disciplines that teach collective health, or the collective health professors, always touch the subject and stay inside a tiny box, kept inside the discipline's box. (SL4)

In my opinion, it is a training problem. Nursing should get out of this little box. (PO2)

The social inequalities are not, but we are doing our best to take it out of the box; it is difficult, and beyond the scope of the curriculum plans, which are the competencies described, the core competencies. [...] But we don't make this a common theme, for example, in training! (PO3)

The difficulties in training are directly reflected in the development of competencies to face social inequalities, understood as a "gap" and the result of "poor political training".

And the university, for I have been watching around, since I've been able to see visiting several states and some universities, I feel that lack of having this calling, coming from the academy to bring to the student: "Let's discuss politics," "Let's think politically". (SL2)

And we observe that there is a macro problem. It starts with training, a historical matter of the constitution of nursing, the professional predilection to discuss technical and not political issues, a poor political training. (PO2)

Militancy is identified in the students' discourse as an opportunity to understand and act on the confrontation of inequalities. In this sense, it is considered a space for the development of competencies with such a focus. The discourses are presented through material processes and cause-effect relations that indicate participation in action (militancy) as a space for the transformation of social actors.

Militancy makes you go back to the communities and outskirts; it makes you redo the speech. Because in academia: if you don't use the technical term, you know nothing. So, if you are a militant, you must not use these terms because people end up not understanding. (SL3)

The representatives of the professional organizations indicated the associative power as a political space to discuss inequalities.

So, we are in this perspective of raising awareness among professionals, performing rounds of conversations with discussion, bringing knowledge, problematizing the Unified Health System, the political moment. [...] We advocate for a corporativism, but I call it progressive corporativism. (PO2)

We have also occupied various discussion spaces, nationally or internationally, always taking a position in defense of the SUS and democracy, as is the tradition. [...] For me, the great rigorousness is to look at the reality, whatever it is, and try to understand that reality to confront the inequities. (PO1)

We work, primarily, strengthening the implementation of public policies, already understanding that public policies in a country of inequality are social policies. So, we work on implementing public policies, the elaboration of public policies [...]. Another thing that we do is researches, extensive researches, that account not only for the panorama of this inequality but also for what can be done to overcome it. (PO3)

Political competence is portrayed in the speeches by representing material processes, whose actions and discursive events are presented with a temporal occurrence that indicates the permanence of these processes over time (leading, problematizing, strengthening). Also, the representation of social actors by inclusion (we, us) signals the individual and collective commitment to confront inequalities through different ways of acting.

\section{DISCUSSION}

The results point out the awareness of social inequality in different aspects and understandings related to economic/financial dimensions, access to education, health, culture, wealth, and poverty. In critical discourse analysis, the lexical elements provide evidence of the representations to be transmitted ${ }^{(12)}$. Thus, the language used expresses the position or point of view on a given phenomenon.

When expressing the understanding of social determinants as a condition that generates inequalities, the participants refer to the factors that affect in different ways, groups, and social classes. In particular, they recognize the historicity and social disadvantages that affect, especially, the outskirts, the poor, black women, and the most vulnerable populations, revealing their worldview through the discourse.

Social determinants of health $(\mathrm{SDH})$ are the conditions that mark the way people live and have an influence on health, including education, employment, income level, gender, ethnicity, housing, and access to health care. Nurses have a long history and a significant role in reducing inequalities and should consider recognizing SDH as a priority to empower individuals and communities in the pursuit of equity ${ }^{(13)}$.

With symbolic strategies of narrativization, universalization, and rationalization, the discourses inform a social practice guided by the ideology of social justice and class struggles. This finding may be related to the profile of the study participants, all linked to spaces of political militancy and professional organization.

The most socially vulnerable groups, with violated human rights, present significant health needs due to subjected privation; however, these groups are the ones who most encounter difficulties in accessing services ${ }^{(14)}$. As we understand that knowledge and resources exist to improve the health of everybody, we will consider such inequities unfair, and avoiding them will be a matter of social justice ${ }^{(15)}$. 
The speeches also refer to the understanding that inequalities, besides being detectable in economic factors, also generate situations of inequity, as they produce damages, create imbalances, and distance people. In this sense, is evident the perspective of equity based on the recognition of ethics and human rights as conceptions that mark the social practice of the discourse on social inequality.

In this context, the discussion about the function of the State takes center stage since it assumes a fundamental role in guaranteeing access to conditions inherent to a citizen. Thus, the reduction of social inequalities and poverty requires significant investments and redistributive policies ${ }^{(15)}$.

The participants weave a critic toward the Brazilian health system, whose historical construction has admitted a subdivision between public and private, with disadvantages for the public part, either because of the population access or the underfinancing. This contradiction inherent in the health system reflects the limits of the Brazilian State's social protection that fails to assist those who need it most due to scarce or subtracted financial resources.

In order to reduce inequalities in access to health care, it is necessary to guarantee the sustainability of the Unified Health System (SUS) and build a culture that is contrary to the predatory logic of the market. In this field, nursing professionals have an indispensable role, both for their numerical expression ahead of the System and their potential to act with individuals and social groups to reverse the situations that produce inequalities.

That nursing commitment with actions to promote justice, provide visibility, and combat unequal relations is a component of the dialectical construction of the profession throughout its social formation, revealing contradictions, limits, and advances.

Historically, laypeople initially cared for patients, and only later, with the advent of Christianity, did" Sisters of Charity" took their place. Furthermore, Christian principles of love of neighbor, altruism, and fraternity ideologically marked the development of nursing.

In the 19th century, in England, modern professional nursing, established by Florence Nightingale, emerged from personal experiences of a privileged aristocratic education, which allowed her to have access to several languages, mathematics, religion, and philosophy, which brought scientific principles to the exercise of care. The foundations that supported the creation of the profession also suffered the influence of religious life and Christian presuppositions of doing God's work, alleviating suffering, helping the weak, following the rules of conduct and ways of caring for the ill, observed during Florence's association with the Sisters of Charity of Saint Vincent de Paul in Paris ${ }^{(16)}$.

Despite that, the professional conformation has an opposite and contradictory pole, also influenced by Florence and her knowledge and performance derived from epidemiological knowledge, her social, political, and educational role in the construction of the profession. Thus, the principles of religiosity and morality that underpinned the profession's creation are associated with the principles of political action in the search for more fair social relations ${ }^{(17)}$.

Florence's legacy demonstrates that nursing practice should be reflective by overcoming technicism and adopting a critical stance, giving the role of nurses a social commitment by always relating knowledge to practice. The historicity of this process carries out the marks of a practice that has been changing over time, and reaches, nowadays, a discursive representation, expressed by the participants as competencies to face social inequalities.

There is a relational identification of nursing in acting and defending against inequalities, especially as part of its work, which is necessary and desirable, in health education, care activities, and encouraging participation. With that, it is built a discourse of accountability, with deontic modalities that reveal the nursing moral mandate and the legacy of Nightingale's political action as an expression of care to promote health ${ }^{(18)}$.

In this direction, the findings indicate that the nurse's behavior in face of social inequalities happens through competencies, especially, advocacy, political competence, leadership, and ethics. The results also point out skills and other attributes that are mobilized when faced with individuals or contexts of inequality: discernment, humanization, sensitivity, empathy.

It is important to emphasize that health advocacy is a core competency for addressing and acting on social inequalities, presented together with political and leadership competencies. As a practice that seeks a fair and representative democracy, advocacy strengthens different social actors in debates of public interest.

The results show that nursing can act against social inequalities through health advocacy, which is, by the way, a current expectation in nursing. However, the analysis of personal correspondence and official documents related to health care in the British armed forces and occupational forces in the Indian continent allows us to identify landmarks of advocacy in Florence's work, especially in the promotion of equal human rights, protection of vulnerable groups, and her leadership activities.

Nightingale carry out actions of defense of nursing and patients by instituting professional training and care standards, taking a leading role in achieving desired changes, and defending an egalitarian value system in healthcare ${ }^{(4)}$. In this sense, the new associated with advocacy in nursing carries the historical marks of acting with political activism. This old-new relation reveals the permanent dialectical movement of social phenomena, which includes nursing.

Mobilization is part of the health advocacy work. In this context, Farrer et al. ${ }^{(19)}$ point out that social mobilization should empower disadvantaged groups to have a voice and build a broad base of support to exert pressure on policymakers. It is possible to identify Florence Nightingale's nursing pioneering in social mobilization initiatives to advocate for progress in the care of patients in the Crimean War and the sanitation conditions in India. Political strategies such as her personal position, communication skills, epidemiological evidence and statistics were found in documents of the period ${ }^{(4)}$.

Social mobilization also includes the influence on electoral processes $^{(19)}$ in an effort of political engagement capable of producing changes in the planning, approval, and implementation of policies. These elements are present in the participants speeches, showing the understanding and practice of advocacy for the defense of equity in an exercise of mobilization, participation, occupation/representation in public spaces/organizations.

The findings lead to the conclusion that political competence is also central to addressing social inequalities and is mixed with advocacy in the interviewees' understanding. 
Sonenberg, Leavitt, and Montalvo(20) present a spectrum of political competence that evolves from an initial level to a more advanced action level. Inside this spectrum, some activities conform to the attributes of political competence such as learning about advocacy and activism, considering health and social issues, engaging in voluntary actions and campaigns, participating in the spaces of democracy, influencing politicians and policies, participating in professional organizations, lobbying, building coalitions, among others.

Thus, it is reaffirmed that, since Florence Nightingale, the political role in the nursing work is emphasized in an understanding that the professional must be involved in class struggles, with political engagement and activism for poverty reduction.

Nursing faces many limits to confront social inequalities, whether in terms of resources and technologies or its professional training, due to its excellent care focus, with restricted knowledge regarding the rule of law ${ }^{(14)}$.

The findings inform that the competencies for acting against social inequalities can be learned and apprehended with emphasis on experiential education. This education sustains itself on in-service learning, with extension and extracurricular activities, articulation with the community and health services, and approaching the spaces of political and social education, militancy and student movement, and associations of the category.

Contradictorily, the research indicates possible flaws in the academic training to act in the face of inequalities from the participants' perspective. Thus, this theme is present in the courses, but with occasional approaches or, many times, individual initiatives. As a dialectical category, contradiction presents itself as a counter position of ideals about the world and generates changes by providing an opportunity for opposition and the (re) construction of a given objective reality.

Discursively, militancy is presented as the action that enables the creation and transformation of the actors. In this sense, it is considered a space for developing competencies to act against social inequalities. In this way, the profession develops, aiming to act beyond the technical, addressing human needs involved in social practices as part of nursing care in its political function.

However, in a study by Laitano et al. ${ }^{(21)}$, militancy in nursing was evidenced as an incipient practice, concentrated in the scope of class entities and movements of associations and students, and commanded mainly by representatives of these organizations. In this sense, it is worth emphasizing a lack of involvement and collective movement to develop militancy actions by the professionals.

With all this information, one can reinforce a historical practice of acting with vulnerable groups, promoting social justice, a political action legacy built since Florence Nightingale.

\section{Study limitations}

This study recognizes the possible influence of the participants' personal, sociocultural, historical, and political contexts on the results found. Also, the small sample size should be considered a limitation.

\section{Contributions to the field of Nursing}

The study contributes to nursing practice, both in education and in the production of care, advancing the agenda of reducing inequalities and building more fair, democratic, and citizen-based relationships.

\section{FINAL CONSIDERATIONS}

The conclusion is that social inequalities are a prominent theme in the discourse of nursing leaders. Their understanding is related to social determinants and the recognition of disadvantages and vulnerabilities that affect different population groups.

For over 200 years, nursing has evolved in its know-how, preserving its centrality and social mandate to promote justice and defense of the vulnerable. We believe in the relevance of continuing discussions and research on this subject, especially considering pedagogical strategies and educational training that can reaffirm and enhance the understanding of inequalities and political action as a legacy of Florence Nightingale to the contemporary nursing.

\section{FUNDING}

Fundação de Amparo à Pesquisa de Minas Gerais (FAPEMIG) and Conselho Nacional de Desenvolvimento Científico e Tecnológico (CNPq).

\section{REFERENCES}

1. Rozendo CA, Santos Salas A, Cameron B. A critical review of social and health inequalities in the nursing curriculum. Nurse Educ Today. 2017;50:62-71. https://doi.org/10.1016/j.nedt.2016.12.006

2. Reutter L, Kushner KE. 'Health equity through action on the social determinants of health': taking up the challenge in nursing. Nurs Inq. 2010;17(3):269-80. https://doi.org/10.1111/j.1440-1800.2010.00500.x

3. Frello AT, Carraro TE. Florence nightingale's contributions: an integrative review of the literature. Esc Anna Nery. 2013;17(3):573-9. https://doi. org/10.1590/S1414-81452013000300024

4. Selanders L, Crane P. The Voice of Florence Nightingale on Advocacy. Online J Issues Nurs. 2012;17(1). https://doi.org/10.3912/OJIN.Vol17No01Man0

5. Bordin V, Almeida ML, Zilly A, Justino ET, Silva NDVS, Faller JW. Liderança em enfermagem na perspectiva de enfermeiros assistenciais de um hospital público da tríplice fronteira. Rev Adm Saúde. 2018;18(71). https://doi.org/10.23973/ras.71.107

6. Magnago C, Pierantoni CR. Nursing training and their approximation to the assumptions of the National Curriculum Guidelines and Primary Health Care. Ciênc Saúde Colet. 2020;25(1):15-24. https://doi.org/10.1590/1413-81232020251.28372019 
7. Thumé E, Fehn AC, Acioli S, Fassa MEG. Formação e prática de enfermeiros para a Atenção Primária à Saúde: avanços, desafios e estratégias para fortalecimento do Sistema Único de Saúde. Saúde Debate. 2018;42(1):275-288. https://doi.org/10.1590/0103-11042018S118

8. Santos JFE, Santos RM, Costa LMC, Almeida LMWS, Macêdo AC, Santos TCF. The importance of civilian nursing organizations: integrative literature review. Rev Bras Enferm. 2016;69(3):572-80. https://doi.org/10.1590/0034-7167.2016690326i

9. Ministério da Saúde (BR). Diretrizes e normas regulamentadoras de pesquisas envolvendo seres humanos. Diário Oficial da União. Resolução do Conselho Nacional de Saúde no 466 de 12 dezembro de 2012 [Internet]. Brasília: MS; 2012 [cited 2020 Apr 29]. Available from: https://conselho.saude.gov.br/ultimas_noticias/2013/06_jun_14_publicada_resolucao.html

10. Minayo MCS. Cientificidade, generalização e divulgação de estudos qualitativos. Ciênc Saúde Colet. 2017;22(1):16-17. https://doi. org/10.1590/1413-81232017221.30302016

11. Associação Brasileira de Enfermagem (ABEn). Conselho Nacional Da Associação Brasileira De Enfermagem. Comitê Estudantil Nacional: Regimento Interno [Internet]. Rio de Janeiro: 2019 [cited 2020 Apr 29]. Available from: http://www.abennacional.org.br/site/wp-content

12. Fairclough N. Discurso e mudança social. Brasília: Editora Universidade de Brasília. 2001. 338p.

13. Hemingway A, Bosanquet J. Role of nurses in tackling health inequalities. JCN Online J [Internet]. 2018 [cited 2020 Sep 23];32(6):62-64. Available from: https://www.jcn.co.uk/journal/12-2018/comment/2073-role-of-nurses-in-tackling-health-inequalities

14. Fiorati RC, Arcêncio RA, Souza LB. Social inequalities and access to health: challenges for society and the nursing field. Rev Latino-Am Enfermagem. 2016;24:e2687. https://doi.org/10.1590/1518-8345.0945.2687

15. Comissão da Organização Pan-Americana da Saúde sobre Equidade e Desigualdades em Saúde nas Américas. Sociedades justas: Equidade em saúde e vida com dignidade. Relatório da Comissão da Organização Pan-Americana da Saúde sobre Equidade e Desigualdades em Saúde nas Américas [Relatório] [Internet]. Washington, D.C, 2019[cited 2020 Sep 23]. 326p. Available from: https://iris.paho.org/ handle/10665.2/51613

16. Padilha MICS, Mancia JR. Florence Nightingale and charity sisters: revisiting the history. Rev Bras Enferm. 2005;58(6):723-6. Available from: https://doi.org/10.1590/S0034-71672005000600018

17. Brandão APCL, Galluzzi ML. Aspectos epistemo-cognitivo-filosóficos no ideário de Florence Nightingale (1890-1910). Rev Scientiarum His [Internet]. 2019 [cited 2020 Apr 30];2:e0100. Available from: revistas.hcte.ufrj.br/index.php/RevistaSH/article/view/100

18. Falk-Rafael A. Speaking truth to power: nursing's legacy and moral imperative. ANS Adv Nurs Sci. 2005; 28(3):212-23. https://doi. org/10.1097/00012272-200507000-00004

19. Farrer L, Marinetti C, Cavaco YK, Costongs C. Advocacy for Health Equity: a synthesis review. Milbank Quarterly. 2015;93:392-437. https://doi. org/10.1111/1468-0009.12112

20. Sonenberg A, Leavitt JK, Montalvo W. Learning the ropes of policy and politics. In: Mason D, Gardner DB, Outlaw FH, O' Grady ET. Policy \& Politics in Nursing and Health. 8. ed. Ed Kindle; 2020. Chapter 4; p. 38-48.

21. Laitano AC, Silva GTR, Almeida DB, Santos VPFA, Brandão MF, Carvalho AG, et al. Precariousness of the work of the nurse: professional militancy from the perspective of the press. Acta Paul Enferm. 2019;32(3):305-311. https://doi.org/10.1590/1982-0194201900042 